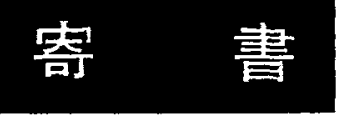

\title{
高 $\mathrm{Ti}-\mathrm{Fe}-\mathrm{Co}-\mathrm{Ni}-\mathrm{Al}-\mathrm{Cu}$ 系磁石の柱状晶の陚作について
}

(A Simple Method to obtain Columnar Magnets of the

Alloy of $5 \% \mathrm{Ti}-\mathrm{Fe}-\mathrm{Co}-\mathrm{Ni}-\mathrm{A} 1-\mathrm{Cu})$

斎 藤 英 夫* 菊 池昭**

(Hideo Saitô and Akira Kikuchi)

$\mathrm{Fe}-\mathrm{Co}-\mathrm{Ni}-\mathrm{Al}-\mathrm{Cu}-\mathrm{Ti}$ 系磁石のうち $\mathrm{Ti}$ 含有量の少ない ものは凝固時に異方性冷却を施すと容易に柱状晶組織をも つものとなり，备粒子の〔100]方向が柱軸方向に揃い，その 方向に扣いて優れた磁気特性を示すことはよく知られてい る.しかて，5\%のTiを含む合金では結晶が碳細化される ため柱状晶組織を得ることが著しく困難とさ れている.わずかに高純度材料による特殊な 例亡して $(B H)_{\max } \sim 11.0 \times 10^{\circ} \mathrm{G}$.Oeのものか 得られている(1)がこれる Gould(2)の記述に したが㓪ば極く少量に限られている。著者ら は容易か力経済的に高 Ti-Fe-Co-Ni-Al-Cu 系磁石の柱状鮊のむのを得る目的で武作を行 ないほぼその目的を達したので以下に報告 する。

素材は $34 \% \mathrm{Co}, 14.5 \% \mathrm{Ni}, 4.5 \% \mathrm{Cu}, 7 \%$ $\mathrm{A} 1,5.10 \mathrm{Ti}$ 残余 $\mathrm{Fe} の$ 標準維成の南販合全 で, $7.5 \phi \times 90 \mathrm{~mm}$ のものである。これい 端を封した石英管に入れ，そして素材の末端 は硝子を溶かして封じた：この管を，最高温 度 $1300^{\circ} \sim 1400^{\circ} \mathrm{C}$ に和いて $28.5^{\circ} \mathrm{C} / \mathrm{cm}$ の温 度勾配安有するシリュニット環状炉の中心軸 上认固定し, 炉を $0.6 \sim 10.1 \mathrm{~mm} / \mathrm{min}$ の速さ

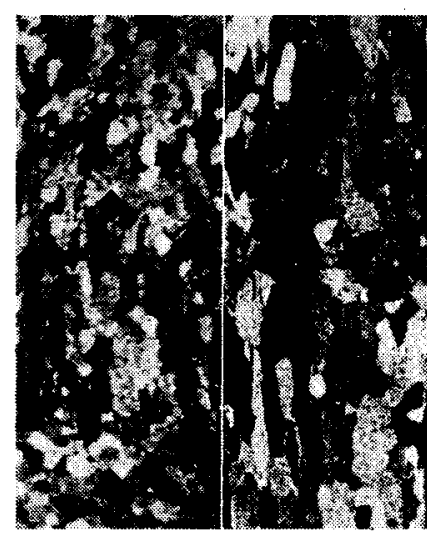

(a)

で上昇させて素材を一端から逐次熔解，凝固させた，次 いで, $6.5 \phi \times 30 \mathrm{~mm}$ に仕上げて試料とし，磁気特珄の测 定と組織観察に供した。な招, 試料忧 $1250^{\circ} \mathrm{C}$ から磁鱼中 で冷却し， $600^{\circ} \mathrm{C} \times 5 \mathrm{hr}$ 焙㳸した。

柱状昌の発羍の度合纫炉の最高温度が $1350^{\circ} \mathrm{C}\left( \pm 10^{\circ} \mathrm{C}\right)$

Table 1 Some examples of magnetic properties of the columnar magnets of the alloy of $5 \% \mathrm{Ti}-\mathrm{Fe}-\mathrm{Co}-\mathrm{Ni}-\mathrm{Al}-\mathrm{Cu}$.

\begin{tabular}{r|c|c|c|c|c|c}
\hline \multirow{2}{*}{ No. } & \multicolumn{2}{|c|}{ Heat treatment } & $\begin{array}{c}B r \\
(\mathrm{KG})\end{array}$ & $\begin{array}{c}H c \\
(\mathrm{Oe})\end{array}$ & $\begin{array}{c}(B H)_{\max } \\
\times 10^{-6}(\mathrm{G} . \text { Oe })\end{array}$ & $\begin{array}{c}\text { Fullness factor } \\
(\%)\end{array}$ \\
\cline { 2 - 7 } & $\begin{array}{c}\text { Max.temp. } \\
\left({ }^{\circ} \mathrm{C}\right)\end{array}$ & $\begin{array}{c}\text { Furnace vel. } \\
(\mathrm{mm} / \mathrm{min})\end{array}$ & & & & \\
\hline $14-2$ & $1415 \pm 10$ & 5.1 & 9.6 & 1310 & 5.00 & 39.7 \\
$18-1$ & $1390^{\prime \prime}$ & 4.7 & 9.6 & 1350 & 5.20 & 40.1 \\
$3-1$ & $1425 " \prime$ & 4.2 & 10.2 & 1320 & 5.90 & 43.8 \\
$2-1$ & $1360 " \prime$ & 2.1 & 10.1 & 1380 & 6.25 & 44.8 \\
$17-1$ & $1370 " \prime$ & 1.5 & 9.4 & 1270 & 5.00 & 41.9 \\
& as cast & & 9.0 & 1290 & 4.30 & 38.6 \\
\hline
\end{tabular}

* 東北大学金属材料研究所 (The Research Institute for Iron, Steel and Other Metals, Tôhoku University, Sendai)

** 特殊製鋼株式会社 (Warabi Special Steel Co., Ltd., Warabi, Saitama Prefecture)
以上であれば，その温度には余り関係せず，移動の速さが

(1) A.I. Luteijn, K.J. de Vos:Philips Res. Rep., 11 (1956), 489 .

(2) J.E.Gould : Cobalt, (1964), No.23,82. 


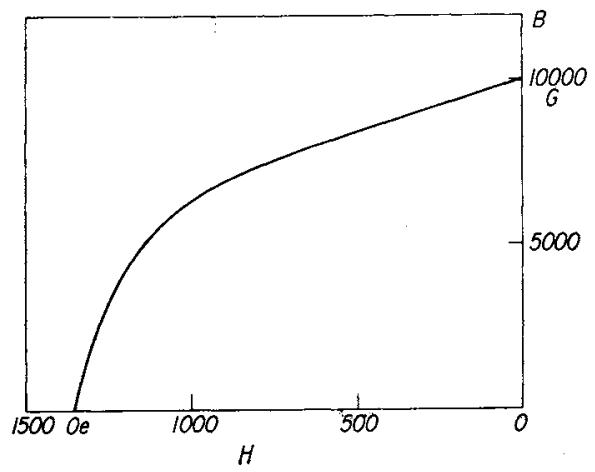

Fig.1 Magnetization curve of a columnar magnet of the alloy of $5 \% \mathrm{Ti}-\mathrm{Fe}-\mathrm{Co}-$ Ni-Al-Cu. (Sp. No. 2-1)

$4 \mathrm{~mm} / \mathrm{min}$ より遅い昜合全面にわたつて発達する，最高 温度が 1350 。 $\mathrm{C}$ 以下の場合には，炉をいかに徐々に移動さ
せても柱状晶は発達しなからた。 Photo. 1 (a) は最高温 度 $1415^{\circ} \mathrm{C}$, 移動速さ $5.1 \mathrm{~mm} / \mathrm{min}$ の場合, (b) 仙 $1415^{\circ} \mathrm{C}$, $4.2 \mathrm{~mm} / \mathrm{min},(\mathrm{c})$ は $1370^{\circ} \mathrm{C}, 1.5 \mathrm{~mm} / \mathrm{min}$ ，むた(d) は $1310^{\circ} \mathrm{C}, 0.6 \mathrm{~mm} / \mathrm{min}$ の場合であつて，上述の事情をよ く示している.とくにPhoto.1(c)の場合にはとくに大きな 粒子が得られ，その中では不純物が直線的に配列している のが認められた。

磁性の数例さ Table 1 K示してある. 柱状晶依表の上 加下に順に発達し，とくに試料 No. 17-1 (Photo.1 (c)) のもので最大であつたが，磁性は必ずしも最適ではなく、 No.2-1，すなわち $1360^{\circ} \mathrm{C}, 2.1 \mathrm{~mm} / \mathrm{min}$ のもので最高の 磁性が得られた。これは移動速さが途すぎる場合には粒 子は大くなっててる一部偏析が起るためと考光られる。

Fig. 1 にはNo.2-1 の磁化曲線を示した。

な技，初期冷却部（下端）飞は $\mathrm{Cu}$ 片など特殊な強制冷却 方法を採る必要がないことも確かめている。 